\title{
Entrepreneurship, Transaction Costs and Cultural Background
}

\author{
Panagiotis E. Petrakis ${ }^{1} \&$ Dionysis G. Valsamis ${ }^{1}$ \\ ${ }^{1}$ Department of Economics, National and Kapodistrian University of Athens, Athens, Greece \\ Correspondence: Panagiotis E. Petrakis, Department of Economics, National and Kapodistrian University of \\ Athens, Athens, 5 Stadiou Str., 105 62, Greece. Tel: 30-210-368-9353. E-mail: ppetrak@econ.uoa.gr
}

Received: February 6, 2013

Accepted: March 14, $2013 \quad$ Online Published: April 17, 2013

doi:10.5539/ibr.v6n5p55

URL: http://dx.doi.org/10.5539/ibr.v6n5p55

\begin{abstract}
This paper aims to explore the connections between transaction costs and economic institutions on the one hand, and the group of variables describing cultural background on the other. By improving transaction characteristics and economic institutions, we can increase the entrepreneurship rates of the society. The paper tries to explore this relationship. Transaction cost and institutional variables are analysed using a principal component analysis and OLS. The results confirm the original working hypothesis of the existence of a relationship between transaction costs and culture. The component of cultural characteristics having a pro-growth orientation reduces transaction costs and enhances economic institutions, while the component of cultural characteristics that are reflected in the pro-social characteristics of cultural background increase it. A positive relationship between entrepreneurial variable and the transaction and economic institutions is revealed.
\end{abstract}

Keywords: entrepreneurship, entry density, cultural background, transaction costs, institutions, principal component analysis, endogeneity

\section{Introduction}

The main purpose of this paper is to identify the extent to which cultural background affects transaction costs and economic institutions, while we examine their contribution in shaping entrepreneurial activity. We wish to add the role of culture in the determination of transaction costs in general to the discussion while empirically testing for endogeneity between the variables used, as we intuitively expect that such a relationship may exist. The relation between economic institutions and entrepreneurship is a crucial issue, which can explain the cross-country differences in economic growth rates.

The role of cultural background has preoccupied researchers in their efforts to explain differences between the economic performance of various countries. The exact impact of culture on economic growth has spurred the interest of disciplines such as economic theory (Schumpeter, 1934), sociology (Weber, 1930) and psychology (McClelland, 1961). Many studies have quantified the "effects" of cultural background and have provided data for a large number of countries (McClelland, 1961; Hofstede, 1980, 2001; House et al., 2004). The relationship between the studies' results and developmental growth indices demonstrates that culture can be particularly valuable (Minkov \& Blagoev, 2009).

Additionally, the institutions of a society form the "rules of the game" (North, 1990) and affect the efficiency of the market. The reduction of transaction costs frees up resources. The existing literature (Acemoglu et al., 2004; Chang, 2006, 2011; Easterly et al., 2006; Hofstede, 1991) supports the notion that cultural background can affect economic output via institutions; i.e., culture is directly linked to the formation of institutions. The establishment of distinguishable frameworks of action for the economic actors can reduce transaction costs, by offering incentives for undertaking entrepreneurial activity.

Hence, a set of relationships is created, which starts from the cultural background of the society and which, through institutions, affects the level of entrepreneurship. Cultural background shapes institutions, influences behaviors and preferences. The emerging economic institutions reflect the culture of each society, by creating the appropriate incentives for starting up a new business.

This paper is organised as follows. Section 2 presents the theoretical work on cultural background and transaction costs economics (TCE) and describes the variables used. Section 3 describes the methodology employed, i.e., the empirical model and measurements, while Section 4 presents the empirical work and a discussion of the results. Finally, Section 5 presents our conclusions. 


\section{The Theoretical Background and the Variables Used}

\subsection{Cultural Background}

Cultural background, and civilisation or culture in general, are concepts based in cultural anthropology and may be defined in a variety of ways. According to Kluckhohn (1954), culture is to society what memory is to people. It includes values, ideas and other symbolic systems that shape behaviours and are passed on from generation to generation (Kluckhohn \& Kroeber, 1952). Similarly, Triandis (1994) believes that anything that was functional at any point in the history of the group deserves to be passed on to future generations. Culture can also be defined as the set of ideas, behavioural theories or mental parameters shared by a group of people (Allaire \& Firsirotou, 1984; Hofstede, 1994). Regarding the economy, North (1990) approaches cultural background as a source of informal limitations that guide our daily transactions and argues that its importance can be measured through formal rules that produce different results when applied to different societies. According to Spranz et al. (2012) culture is the ongoing interplay between formal rules and informal constraints that emerges in the historical development of every society.

Oyserman and Sorensen (2009), using the term "cultural syndromes", and Triandis (1996), define sets of interconnected features that overlap and sometimes contrast and, depending on the circumstances, either periodically rise to the surface or descend into oblivion. Therefore, cultural background includes ways of thinking and producing meanings, i.e., mental states or representations. Examples of a cultural syndrome are individualism and collectivism.

In contrast, Schwartz (2009) considers cultural background to be an exogenous variable in relation to one's self. Although it is not a condition established in the human mind, it affects the behaviour of individuals through linguistic communication, regulations and expectations. However, it is difficult to accept an extra-personal construct, as the production of culture is an intrinsic process of the human species.

Hofstede $(1980,1991)$ develops a model that analyses social values and the structure of enterprises in a society, based on their cultural backgrounds, which he divides into five cultural dimensions (Note 1). His model has been used by many researchers (Rapp et al., 2011) to explain various processes, such as the ethics of negotiations (Volkema, 1999), strategies for entering a market (Anderson \& Coughlan, 1987) and the analysis of international markets (De Mooij, 1998).

\subsection{Transaction Costs}

The theory of transaction cost economics (TCE) was first proposed by Coase (1937), but was promoted to a wider public by Williamson $(1975,1985)$. One of the key issues of interest for economists within New Institutional Economics is the study of transaction costs. According to Arrow (1969), transaction costs are the same as the costs for the "operation" of the financial system. The concept of transaction costs has led to a variety of different ways of thinking regarding both the design and organisation of production and in the creation and evolution of institutions. The focus is primarily on how transaction costs are measured. TCE provides a theory to explain the choice for efficient governance structures (Spithoven, 2012).

The 1930s saw the formulation of the theory of transaction costs, in particular, through the contributions of Commons (1934) and Coase (1937). Commons (1934) was the first to notice that transaction costs are central to economic analysis. Essentially, however, the core of the theory was developed by Coase (1937) in his article "The Nature of the Firm". According to Coase, transaction costs are nothing but the cost that accompanies the exchange of goods. The role of transaction costs is important for the interpretation of the structure of the market (Coase, 1937, 1960).

The behavioural characteristics on which the theory of transaction costs is supported are summed up in bounded rationalism and opportunity exploitation (Williamson, 1981), characteristics that affect and are affected by each society's cultural background. According to Williamson (1981), the characteristic of "bounded rationalism" does not entail a lack of logic or irrational thought. On the contrary, it involves a limited capacity for the resolution of difficult and complex problems of data analysis and information processing, as well as a lack of specialisation. Furthermore, individuals engage in transactions and make contracts when their goals are met, according to opportunistic behaviour (Williamson, 1985; Conner \& Prahalad, 1996).

The basic features of transactions are uncertainty, frequency and asset specificity (Williamson, 1981) and they are part of markets and public governance (Williamson et al., 2007). All of these components are shaped according to the cultural background and the overall organisation of each society. In general, as the degree of uncertainty concerning a transaction increases, there is a burden on transaction costs because of the unpredictable result of the transaction. Transaction uncertainty ultimately places an uncertainty premium on 
transaction costs.

Institutions set the "rules of the game" in a society (North, 1990). They are defined as society's collective choices that usually express conflicts of interest and develop under the influence of history and cultural background. Generally, favourable economic institutions (with respect to growth) are those that offer secure property rights across a wide range of society's functions (Acemoglu et al., 2004; Chang, 2006; Dutt, 2011). This paper does not extend its analysis to political institutions but only to the economic ones that shape incentives in a society, including incentives regarding physical capital, human capital, technology and the organisation of production (Economides et al., 2009). The primary expressions of economic institutions are property rights, contractual conditions and, ultimately, the magnitude of those conditions' effects on economic transactions.

The different social and political processes that shape each society's cultural background guide human behaviour and the characteristics of those involved. For instance, Greif (1994) concludes that the effect of culture is significant in a) shaping the institutional structure, b) planning for the future and its co-dependence with institutions, and c) preventing the acceptance of foreign culture's institutions.

\subsection{Cultural Background and Transaction Costs}

The existence of cultural differences in societies with respect to perceptions of transaction costs provides an important extension of transaction cost theory. Economic institutions, in the form of property rights and contractualisation, are influenced by the characteristics of trade, cultural stereotypes (Boyer \& Petersen, 2012) and elements of human behaviour. Furthermore, institutions are shaping each agent's action (Hédoin, 2012).

Cultural background is a determinant of consumer behaviour (Clevelant \& Laroche, 2007), and the study of this relationship is particularly important when choosing a strategy for the international expansion of activities and transactions.

Greif (1994) highlights that different cultural values lead to different types of social structures in economic relations and influence the dynamics of wealth distribution. He separates societies into those characterised by privacy (Individualist societies) and those characterised by collectivity (Collectivist societies) and describes their characteristics, concluding that a system of collectivity tends towards a stable model for the distribution of income. Societies characterised by strong elements of privacy encourage low levels of communication between their members, a vertical social structure and weak forces of informal financial enforcement. Individuals have low levels of responsibility and "self-punishment" and therefore do not do what is right. A model that incorporates privacy is less effective in supporting inter-economic relations and requires costly and formal organisations (contract enforcement is achieved mainly through specialised organisations, such as courts). Moreover, Greif's analysis concludes that the western societies that are more effective in their operation in the long-term are based on the privacy model.

Shane $(1992,1993)$ seeks to connect the effects of cultural differences in the perceptions of transaction costs observed between societies, the differences in societies' preferences for licensing and international joint ventures. He contends that an appropriate cultural variable is "Power Distance", as presented by Hofstede (1980), which is an expression of the degree of interpersonal trust in a society. He concludes that a high score of the power distance index in a society (low levels of interpersonal trust) increases transaction costs and reduces the cost of government, increasing the preference of a society for wholly owned subsidiaries compared to joint ventures through foreign direct investment (Shane, 1993).

M. Chen et al. (2002), attempting to include cultural characteristics in transaction cost theory, conclude that in transactions within the same group, whether these concern individuals or organisations, cultures characterised by privacy display more opportunistic behaviour compared to those characterised by collectivity, while in transactions with other groups, collectivists display more opportunistic behaviour.

Hofstede et al. (2008a) focus on the influence of the cultural characteristics of a society on the choices made in transactions. The transactions model they use is based on transaction cost theory and includes the procedures for searching, bargaining, contracting, monitoring and enforcing contracts. Hofstede et al. (2008b) focus on the "Uncertainty Avoidance" cultural variable, as interpreted by Hofstede (1980), and conclude that individuals in societies with low scores for this variable interact more easily with strangers. Hofstede et al. (2008b) conclude that in societies with dominant elements of either privacy or collectivism, i.e., with a low/high privacy/collectivism index as described by Hofstede (1980), the value of transactions is relatively high. However, in societies where privacy and collectivity co-exist, the value of transactions is lower, as collectivists end up transacting with members of the groups to which they belong. Examining the impact of the value of the short-term/long-term orientation variable (Hofstede, 1980) on transactions, Hofstede et al. (2008b) conclude that 
in societies with a high short-term orientation, people pursue strategies based on the qualitative characteristics of transactions, feel insecure about the behaviour and choices of the individuals with whom they transact, display opportunism and seek agreements with persons well established in society. Moreover, Hofstede et al. (2008b) examine the relationship between the cultural variable for the acceptance of inequalities (Hofstede, 1980) and trade (Hofstede et al., 2008b). They observe that in societies with high values of the variable, when the party being approached is sufficiently high in the social hierarchy, transactions are achieved more easily and quickly and are characterised by greater patience regarding the behaviour and choices of the transacting party.

In their analysis, C. Chen et al. (2002) attempt to identify the factors that shape opportunistic behaviours, in response to the criticism received by TCE regarding the basic assumption of opportunism being human nature. For C. Chen et al. (2002), the role of culture is an important factor influencing human behaviour. Based on data from sociology and psychology, they suggest that the tendency of individuals towards opportunism is affected by the degree of privacy/collectivity and the set of their moral barriers. However, as reported by Ghoshal and Moran (1996), this opportunistic propensity does not mean that a person with such a propensity will routinely behave opportunistically in all transactions.

Going one step further, Gazendam and Jorna (2005) find that the TCE hypotheses regarding the architecture of actors do not agree with the data on cognition and intelligence in cognitive science. Despite the basic assumptions of TCE regarding confidence/uncertainty, commitment and opportunism, there is no reference supporting the so-called "intelligence of actors". Gazendam and Jorna's (2005) criticism is clearly expressed when they note that "Bounded rationality is assumed but not incorporated, learning is assumed but not accounted for". Thus, they divide the examination of TCE between two levels: an intentional level (trust, opportunity, loyalty) and a functional level (bounded rationality, learning); in so doing, they include elements of cultural background in their concept of transaction costs.

\subsection{Entry Density, Transaction Costs and Economic Institutions}

The notion of entrepreneurship and its contribution to the economic science as a factor for economic growth has been analyzed by many scholars (Schumpeter, 1934, 1950; Audretsch, 2007; Knight, 1971; Wang, 2012).

The relationship between cultural background, transaction costs (via institutions) and entrepreneurship has spurred the interest of the researchers. Cultural background shapes the institutions of the society. Well-established institutions can reduce the transactions costs creating incentives for entrepreneurship. Weber's (1930) "The Protestant Ethic and the Spirit of Capitalism" is the most well known attempts to link cultural values with economic behavior explaining the role of capitalism in economic development. Baumol (1990) considers that institutions, resources and history, among other factors, determine the success of an entrepreneurial activity.

Audretsch (2009) introduced the term "entrepreneurship capital" in the framework of entrepreneurship, by referring to institutions, culture and the historical context that contribute to starting up a new business. Entrepreneurship capital includes a multitude of aspects, such as the degree to which society accepts entrepreneurship, as well as the intention of the individual to share risks and benefits.

In general, we can approach the relationship between cultural values and entrepreneurial activity from two different perspectives. In the first one, the supply or "pull" perspective, we have the "legitimation of entrepreneurship" and the "aggregate psychological traits", whereas in the demand side we have the "dissatisfaction perspective" for business start-ups and entrepreneurship in general (Verheul et al., 2002; Wennekers et al., 2008).

Transaction uncertainty ultimately gives an uncertainty premium to transaction costs. This results in the increase of the level of risk of the economy, which discourages investors from undertaking entrepreneurial initiative. Well-established markets, which offer efficient transactions by limiting obstacles in transactions, offer the businessman the incentive to enter in it, increasing in this manner entry density. At the same time, an enterprise with an effective transaction costs management mechanism has a comparative advantage compared to its competitors (Spulber 2003, 2008), by means of freeing up resources it can dispose of for new investments, as well as for the productive procedure.

As far as economic institutions are concerned, the country institutional profile is frequently used to study entrepreneurial activity. The relationship between institutional background and economic growth and, thus, with entrepreneurship stems from three different sources from their: a) contribution to coordination and governance, b) influence on the process of knowledge development and c) effect on income distribution and on development of social coherence (Easterly et al., 2006). 
A multitude of factors define the relationship between entrepreneurship and economic growth. At a macro level, it includes factors such as business climate, education levels, and political and legal conditions (Grilo and Thurik 2005; Hwang and Powell, 2005; van Stel et al., 2005). At an institutional level, factors that determine entrepreneurial incentives are the regulation of product markets, the start-up costs, the regulatory burden on the firms, the social security system and cultural values vis-à-vis entrepreneurship and self-employment (Parker, 2007; van Stel et al., 2007).

The effects of specific entrepreneurial policies, their characteristics and their implementation cover a large part of the literature on entrepreneurship (Stevenson \& Lundström, 2005, 2007; Audretsch et al., 2007; Hoffmann, 2007). Wennekers et al. (2002) stress out that institutions, in conjunction with government policy influence the opportunities for starting up a business. The clear institutional and legal environment, the smooth operation of the markets under specific rules, privatisation and collectivization create the requirements for entrepreneurial opportunities. The government's ability to provide institutions through an effective rule of law (Kaufmann et al., 1999; Hellman et al., 2000; Kaufmann et al., 2008) and the protection of property rights (North, 1981; Acemoglu \& Johnson, 2005) seem to be fundamental parts of entrepreneurial growth.

\subsection{The Data}

The selection of the variables in this paper was aimed at creating the Principal Components (PCs) through the Principal Component Analysis (PCA) method for two groups of variables: 1) the cultural background and 2) transaction costs and economic institutions.

The selection of variables representing the cultural dimensions and the transaction and specifying variable characteristics that capture the economic institutions is rather difficult because specific variables are a) very difficult to quantify and b) even if they are quantified, it is not certain that they are collected and registered in a satisfactory manner at the societal level.

Cultural background measurements originate from House et al. (2004) and are more recent (1995-1997) than Hofstede's.

However, Freytag and Thurik (2007, 2010), in discussing the way in which cultural variables affect real ones (in the case of entrepreneurship), conclude that country-specific cultural variables seem to explain social preferences but not actual activity, i.e., what we observe is mainly the result of actual economic conditions and not reflections of the cultural background. However, ignoring the influences of cultural background on actual activity is not intuitively correct because certain cultural traits (i.e., uncertainty avoidance or collectivism) have prevailed for long periods, and their presence is detected repeatedly through numerous social expressions. A compromise resolution to this problem is to rely on cultural values reflecting adopted practices (as they are) and not in beliefs and values (what should be), as we do in this paper.

Cultural background is expressed in the variables developed by Globe (House et al., 2004): performance orientation, future orientation, gender egalitarianism, assertiveness, institutional collectivism, in-group collectivism, power distance, human orientation and uncertainty avoidance.

Quantifying transaction costs is challenging. Variables that can adequately present the objective characteristics of frequency and asset specificity could not be found. A process that has been adequately quantified is the number of transactions in an economy. An economic system with a number of transactions pertaining to its operational processes and not the economic result of its production system, displays unique characteristics in comparison to another, where transactions exhibit a strong productive orientation (without bureaucracy, corruption etc.). We use the variable starting business, which measures time (calendar days) required to begin a company's operation, as a sign of its transactions' development, with production (developmental) orientation of the transactions' organization, as a point of reference.

Furthermore, the risk that prevails in an economy can be adequately described by using the composite risk as a proxy.

For the expression of the economic institutions, we will use the following variables: property rights and rule of law. Note that the relationship between cultural background and economic institutions (De Jong, 2011) should not be taken for granted as being a positive one, as it has been demonstrated that the opposite relationship may hold (Ahlerup et al., 2009).

In order to measure the entrepreneurial activity in an economy, a variety of variables can be used. Self-employment, total early stage entrepreneurship activity (from Global Entrepreneurship Monitor) and entry density (World Bank) are some of the most widely used ones in literature. The World Bank, in order to measure entrepreneurial activity, collects annual cross-country data on new business registration. In this paper we use 
entry density as a representative variable for measuring entrepreneurial activity.

Table 1 presents the variables used, their reference periods and their sources.

Table 1. Sources and periods of reference in the variables

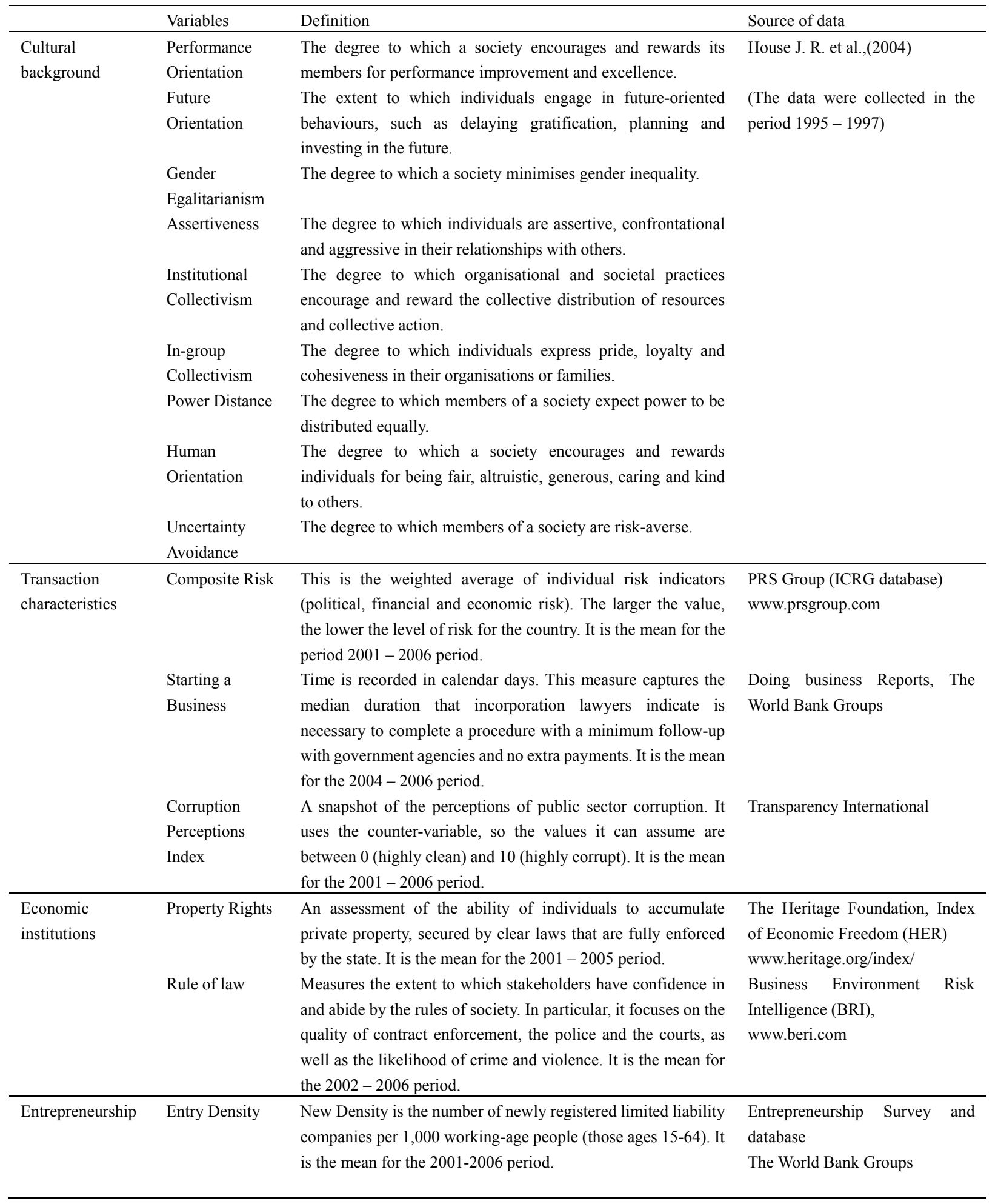

The 41 countries that constitute the sample represent 90.44\% of World GDP for 2007 (IMF Database). The countries are as follows: Argentina, Australia, Austria, Brazil, Canada, China, Colombia, Denmark, Ecuador, Finland, France, Germany, Greece, Hong Kong, Hungary, India, Indonesia, Ireland, Israel, Italy, Japan, Malaysia, 
Mexico, Netherlands, New Zealand, Philippines, Poland, Portugal, Russian Federation, Singapore, Slovenia, South Africa, South Korea, Spain, Sweden, Switzerland, Thailand, Turkey, United Kingdom, USA, Venezuela.

It is clear from the way the data are collected that we treat the world as a typical country, as we do not allow for heterogeneous growth experiences; we suppose that the production process is homogenous around the world (Bos et al., 2010). This assumption is because the limited degrees of freedom due to the small sample of observations (mainly the limited number of observations for the cultural variables) do not permit a deepening of the relevant analysis.

\section{The Methodology Employed}

The basic model examined is the following:

$$
T I_{i}=\beta_{0}+\beta_{i}^{*} \text { CULTURAL BACKGROUND }{ }_{i}+\varepsilon_{i}
$$

where the dependent variable $\left(\mathrm{TI}_{i}\right)$ expresses transaction costs and economic institutions, and the independent variable CULTURAL BACKGROUND $i$ represents the cultural backgrounds of the 41 countries in the sample. The subscript $i$ refers to the countries used.

To represent the complexity of the model's variables, we employed the Principal Component Analysis (PCA) method. PCA is a useful econometric method that is applied to find common characteristics in high dimension data and expresses the data in a way that stresses similarities and differences. By employing PCA, the number of variables representing cultural background and transaction costs is reduced, and the structure of the relationship between these variables is detected without much loss of information. Smith (2002), in the "Tutorial on Principal Components Analysis", notes that PCA is a way of identifying patterns in data and expressing data in such a way as to highlight similarities and differences. More specifically, PCA is a factor extraction method used to form uncorrelated linear combinations of the observed variables, which are then used to obtain the initial factor solution when a correlation matrix is singular. The first principal component (PC) has a maximum variance. Successive components progressively explain smaller portions of the variance and have no correlation with each other.

We apply PCA to two groups of variables. One group contains variables expressing transaction costs and institutions, and the other group contains variables expressing cultural background. The effect of culture on transaction costs and economic institutions is expressed through a linear regression analysis using the ordinary least squares method (OLS), as in the model presented above. In our linear regression, we used the principal components with the greatest variances (initial eigenvalues $>1$ ).

To check for endogeneity between the variables used, we use a version of the Hausman test (Hausman, 1978) proposed by Davidson and MacKinnon $(1989,1993)$, which employs a test statistic for exogeneity by running an auxiliary regression. The Hausman test examines the degree to which the interpretative variables of a regression suffer from endogeneity due to omitted variable bias, measurement error or reverse causality. The null hypothesis states that the model yields consistent estimates, and the reported values of p-value state the probability that the test statistic is zero, which would imply the acceptance of the null hypothesis. In this test, we use a set of instrumental variables that are correlated with the "suspect" variable but not with the error term of the regression that uses $\mathrm{TI}_{i}$ as a dependent variable. The OLS estimates will only be consistent and unbiased if there is no endogeneity. In addition, the partial instrumental variables $\mathrm{R}^{2}$ are reported to describe how much of the squared residuals can be explained by the instrumental variables. The partial p-value, which is the probability that the F-value for each instrumental variable is zero, is also reported.

If we identify endogeneity between the variables used, the structural system of the two equations (one equation for each of the endogenous variables as a dependent variable) will be estimated using two-stages least squares (2SLS). In this method, we will use the variables that seem to have no direct causal link to the endogenous variables, (which have disturbance terms that are correlated with that of the problematic causal variable) as exogenous variables. This method covers models that violate the ordinary least squares (OLS) assumption of recursivity (when the model involves feedback loops), specifically models in which the disturbance term of the dependent variable correlates with the cause(s) of the independent variable(s). In the first stage, new dependent or endogenous variables are created to substitute for the original variables by using selected instrumental variables, which replace the problematic causal variables so as not to violate the OLS regression's recursivity assumption. In the second stage, the regression is computed in OLS fashion, but with the newly created variables.

\section{Empirical Work and a Discussion of the Results}

The results of the empirical work are presented in this section. The various variables expressing transaction costs 
and economic institutions lead to a PC that captures $82.34 \%$ of the total variance and presents an initial eigenvalue of 4.117. As seen in Table 2, the PC of transaction costs and economic institutions (TI) is negatively shaped by starting a business and positively shaped by corruption, composite risk, property rights and rule of law. Overall, this PC demonstrates the characteristics of transactions and economic institutions (TI). Increasing values of TI indicates decreasing transaction costs and improvement of economic institutions in the economy.

Regarding cultural background, we extracted two PCs (Table 3) that explain $61.03 \%$ of the total variance and present an initial eigenvalues of $3.795(42.16 \%)$ and $1.698(18.87 \%)$. The first PC for Cultural Background $\left(\mathrm{C}_{1}\right)$, which exhibits a Pro-Growth Orientation, is determined by the positive effect of performance orientation, future orientation, institutional collectivism, human orientation and uncertainty avoidance, and the negative effect of assertiveness. An increase in the value of Pro-Growth Orientation means an improvement in the cultural background of a society. The second PC for Cultural Background $\left(\mathrm{C}_{2}\right)$, described as a Pro-Social Orientation, is determined by the positive effect of gender egalitarianism and assertiveness, and the negative effect of institutional collectivism, in group-collectivism, power distance and human orientation. An increase in the value of Pro-Social Orientation leads to an aggravation of the elements of the cultural background relating to the qualitative features of a society.

Tables 2 and 3 present the contents of TI, $\mathrm{C}_{1}$ and $\mathrm{C}_{2}$, i.e., the variables that affect the PC configuration, but only for values of partial correlations greater than 0.3 .

Table 2. Principal component matrix of transaction costs

\begin{tabular}{llc}
\hline & & Transaction costs and economic institutions (TI) \\
\hline Transaction Characteristics & Starting a business & -0.75 \\
& Corruption & 0.97 \\
& Composite risk & 0.88 \\
\multirow{2}{*}{ Economic Institutions } & Property rights & 0.95 \\
& Rule of law & 0.97 \\
\hline
\end{tabular}

Table 3. Principal component matrix of culture

\begin{tabular}{lcc}
\hline & Pro-Growth Orientation $\left(\mathrm{C}_{1}\right)$ & Pro-Social Orientation $\left(\mathrm{C}_{2}\right)$ \\
\hline Performance Orientation & 0.73 & \\
Future Orientation & 0.80 & 0.44 \\
Assertiveness & -0.37 & -0.45 \\
Power Distance & -0.78 & 0.47 \\
Uncertainty Avoidance & 0.88 & -0.33 \\
Gender Egalitarianism & & -0.59 \\
Institutional Collectivism & 0.75 & -0.72 \\
In-group Collectivism & -0.60 & \\
Human Orientation & 0.37 & \\
\hline
\end{tabular}

Table 4 presents the correlations between the variables used in the basic model. Observing the correlation matrix below (Table 4), we believe that TI may be endogenously determined by $C_{1}$ or $C_{2}$. For this reason, we saw the need to check for the possible existence of endogeneity between TI and $C_{1}$ or $C_{2}$ using the exogeneity test developed by Davidson and MacKinnon $(1989,1993)$. The selection of the appropriate instrumental variable is a demanding and time-consuming process, as we need to locate a variable that will present a high correlation, satisfactory $\mathrm{R}^{2}$ and an F-statistic $>10$ with respect to $\mathrm{C}_{1}$ or $\mathrm{C}_{2}$, while presenting a low correlation, a low $\mathrm{R}^{2}$ and an F-statistic $<10$ with TI. The Trust in Justice and Police variable is considered a strong instrumental variable, as it is estimated to have a partial F-statistic of 10.46 , while $22.51 \%$ of the squared residuals can be explained by the instrumental variable, according to the partial $\mathrm{R}^{2}$. In addition, the Trust in Justice and Police variable appears to be correlated with $\mathrm{C}_{1}(0.47)$, constituting an additional indication for the existence of endogeneity. Additionally, we should note that, based on a regression of the Trust in Justice and Police on TI, the partial F-statistic is estimated to be $3.93(\mathrm{~F}$-stat $<10)$ and the partial $\mathrm{R}^{2}$ is only $9.84 \%$. Thus, the Trust in Justice and Police variable can be regarded as exogenous with respect to TI. Repeating the above process to find the instrumental variable for $\mathrm{C}_{2}$, we find that the GDP Growth variable is a strong instrumental variable because it is estimated to have a partial F-statistic of 20.26 and an $\mathrm{R}^{2}$ of $34.19 \%$. Regressing GDP Growth on TI, the partial F-statistic is estimated to be 6.96 , and the partial $\mathrm{R}^{2}$ equals $15.14 \%$. Thus, GDP Growth can be regarded as an exogenous variable in relation to $\mathrm{TI}$. 
Table 4. Correlation matrix

\begin{tabular}{lcc}
\hline Variable & Transaction costs and economic institutions $(\mathrm{TI})$ & Pro-Growth Orientation $\left(\mathrm{C}_{1}\right)$ \\
\hline Pro-Growth Orientation $\left(\mathrm{C}_{1}\right)$ & $0.651^{* * *}$ & $4.47 \mathrm{E}-16$ \\
Pro-Social Orientation $\left(\mathrm{C}_{2}\right)$ & $-0.488^{* * *}$ & \\
\hline
\end{tabular}

Note: ${ }^{\text {a }}$ Significance at the $1 \%$ level is denoted with $* * *$.

To apply the exogeneity test, we run two OLS regressions. In the first regression, we regress $C_{1}$ on $C_{2}$ and the Trust in Justice and Police instrumental variable and retrieve the residuals. In the second regression, we re-estimate the basic model including the residuals from the first regression as additional regressors. We find that the first stage residuals are not significantly different from zero and there is no endogeneity problem between TI and $\mathrm{C}_{1}$. Similarly, regressing $\mathrm{C}_{2}$ on $\mathrm{C}_{1}$ and the GDP Growth instrumental variable, we take the residuals and re-estimate the basic model including the residuals from the first regression. In this case, the residuals are also not significantly different from zero, and thus, the model is not affected by an endogeneity relationship and provides consistent and unbiased estimates.

Table 5. Regression results

\begin{tabular}{lc}
\hline Dependent variable & Basic model \\
& Transaction costs and economic institutions (TI) \\
\hline Pro-Growth Orientation $\left(\mathrm{C}_{1}\right)$ & $0.63^{* * *}$ \\
& $(6.52)$ \\
Pro-Social Orientation $\left(\mathrm{C}_{2}\right)$ & $-0.49^{* * *}$ \\
& $(-5.13)$ \\
\hline Adjusted $\mathrm{R}^{2}$ & $64.5 \%$ \\
F-statistic & $34.49^{* * *}$ \\
\hline
\end{tabular}

Notes: ${ }^{a}$ The parenthesis include the t-statistics for the coefficients of regressions. ${ }^{\mathrm{b}}$ Significance at the $1 \%$ level is denoted ***.

Table 5 presents the empirical results of the estimated regression. The basic model estimates the effect of a Pro-Growth Orientation $\left(C_{1}\right)$ and a Pro-Social Orientation $\left(C_{2}\right)$ on TI. An increase in $C_{1}$ would positively affect $\mathrm{TI}$, as they present positive and statistically significant estimates. In contrast, $\mathrm{C}_{2}$ presents a negative relationship with TI. The Adjusted $\mathrm{R}^{2}$ of the regression amounts to $64.5 \%$, while according to the F-statistic, the regression is statistically strong.

Interpreting the results, we find that improving the Pro-Growth Orientation tends to reduce transaction costs and enhance economic institutions because societies are future-oriented, focus on performance, prefer the future to the present, accept the risk of undertaking long-term initiatives and display reduced collectivism, being oriented towards individual action.

In contrast, increasing a Pro-Social Orientation contributes to increased transaction costs and inefficient economic institutions. Characteristics such as authoritarianism and aggression in a society, low levels of gender equality, orientation towards the individual and a limited commitment to institutions decrease confidence and increase uncertainty.

In order to examine the relationship between transaction costs and economic institutions, we run a correlation analysis. The lack of statistical data prevents us from running a more advanced econometric analysis (e.g. a 2 SLS regression analysis), given that the degrees of freedom would be limited in this way.

The reduction of transaction costs and the improvement of the economic institutions of the society function towards improving entrepreneurship. As it appears in Table 6, the principal component of transaction costs and economic institutions (TI) is positively associated with entry density.

Table 6. Correlation matrix

\begin{tabular}{lc}
\cline { 2 - 2 } Variable & Entry Density \\
\cline { 2 - 2 } Transaction costs and economic institutions (TI) & $0.503^{* * *}$ \\
\hline
\end{tabular}

Note: ${ }^{\text {a }}$ Significance at the $1 \%$ level is denoted with $* * *$.

Economies that tend to improve the function and the effectiveness of their institutions, as well as to manage effacing transaction costs by reducing bureaucratic procedures, have a comparative advantage with regard to 
attracting new investments and undertaking large-scale entrepreneurial initiatives.

\section{Conclusion}

The present paper at first aimed to examine the extent to which cultural background affects transaction costs and economic institutions and secondly to identify to what extent economic institutions and transaction costs are related with entrepreneurship. The role of culture in shaping transaction characteristics and economic institutions has spurred the interest of researchers. However, despite it being intuitively easy to understand the existence of this relationship, it is difficult to quantify it.

To a great degree, this paper has succeeded in quantifying these variables and highlighting the importance of culture in shaping transaction costs and economic institutions. To this end, this paper allowed these variables to co-operate and influence one another by using the Principal Analysis and Regression Analysis methods. We did not locate any endogeneity problems between the variables in our empirical analysis, thus achieving consistent and unbiased estimates through OLS.

The empirical results are quite encouraging. The regression model shows that the PCs describing cultural background significantly affect transaction costs and economic institutions. More specifically, according to the Pro-Growth Orientation measure, societies oriented towards rewarding the performance of their members in designing, planning and investing in the future and that are risk-averse tend to reduce transaction costs and promote the orderly functioning of economic institutions. The existence of a strong regulatory framework that protects property rights leads to a reduction in the cost of transactions. The confidence of a society in its laws and compliance with its institutions creates coherent links, simplifying the transaction process and the number of contracts. The second PC of culture, the Pro-Social Orientation, which focuses on the factors that promote the improvement of societies, shows that the elimination of long-term structures and stereotypes is essential for reducing transactions. The reduction of inequalities, an orientation towards more "feminine" values and respect for institutions and rules can lead to reduced transaction costs, encouraging long-term economic growth.

As far as economic institutions and entry density are concerned, we find a statistical significance relationship between the two.

The policy implications of the paper's findings are clear: improving the cultural background of a society, particularly certain aspects of it, may contribute to reducing transaction costs. Nevertheless, by reducing transaction costs and strengthening the efficiency of economic institutions, the appropriate prerequisites for enhancing entrepreneurship are created.

Nevertheless the cultural change is a long-lasting process. Policymakers need to make a great effort to improve some basics aspects of a society's cultural traits. However, the improvement of economic and political institutions may help this procedure. A future study may examine which cultural traits of a society are consistent or not over extended periods of time.

Policymakers should understand the significance of institutions as a source of productive entrepreneurship activity and implement policies, which will focus on that direction. The basic purpose of economic policy should be the creation of an institutional framework, which would emphasize on new entrepreneurial initiatives.

Future research may explore the roles of cultural background, transaction characteristics and economic institutions in when determining the variables to represent economic growth, as part of the "remaining factors" in the growth process, while co-operating with the capital, labour and human capital factors, in the framework of a complete growth theory. Furthermore, it could be further extended by checking for the effects of special circumstances that improve the entrepreneurial activity in the societies, using a sensitivity analysis.

\section{References}

Acemoglu, D., \& Johnson, S. (2005). Unbundling Institutions. Journal of Political Economy, 113, 949-995. http://dx.doi.org/10.1086/432166

Acemoglu, D., Johnson, S., \& Robinson, J. A. (2004). Institutions as the fundamental cause of long-run growth. CEPR Discuss Pap, 4458.

Ahlerup, P., Olsson, O., \& Yanagizawa, D. (2009). Social capital vs institutions in the growth process. European Journal of Political Economy, 25(1), 1-14. http://dx.doi.org/10.1016/j.ejpoleco.2008.09.008

Allaire, Y., \& Firsirotu, M. E. (1984). Theories of Organizational Culture. Organizational Studies. http://dx.doi.org/10.1177/017084068400500301

Anderson, E., \& Coughlan, T. A. (1987). International market entry and expansion via independent or integrated 
channels of distribution. Journal of Marketing, 51(1), 71-82. http://dx.doi.org/10.2307/1251145

Arrow, J. K. (1969). The organization of economic activity: Issues pertinent to the choice of market versus non-market allocations. Analysis and Evaluation of Public Expenditures: The PPP System, 1, 47-64. Washington, D.C., Government Printing Office, Washington.

Audretsch, D. B. (2007). The entrepreneurial society. New York: Oxford University Press. http://dx.doi.org/10.1093/acprof:oso/9780195183504.001.0001

Audretsch, D. B. (2009). The entrepreneurial society. Journal of Technology Transfer, 34, 245-254. http://dx.doi.org/10.1007/s10961-008-9101-3

Audretsch, D. B., Grilo, I., \& Thurik, R. (2007). The Handbook of Entrepreneurship Policy (pp. 1-17). Cheltenham: Edward Elgar Publishing Limited, UK and Northampton, MA, US.

Baumol, W. J. (1990). Entrepreneurship: Productive, Unproductive and Destructive. Journal of Political Economy, 98, 893-921. http://dx.doi.org/10.1086/261712

Bos, J. W. B., Economidou, C., Koetter, M., \& Kolari, J. W. (2010). Do all countries grow alike? J. of Dev. Econ., 91(1), 113-127. http://dx.doi.org/10.1016/j.jdeveco.2009.07.006

Boyer, P., \& Petersen, M. (2012). The naturalness of (many) social institutions: evolved cognition as their foundation. Journal of Institutional economics, 8(1). http://dx.doi.org/10.1017/S1744137411000300

Chang, H. J. (2006). Understanding the relationship between institutions and economic development: Some key theoretical issues. World Institute for Development Economic Research (UNU-WIDER), Working Papers DP2006/05.

Chang, H. J. (2011). Institutions and Economic Development: Theory, Policy and History. Journal of Institutional Economics, 7(4). http://dx/doi.org/10.1017/S1744137410000378

Chen, C., Peng, M. W., \& Saparito, P. A. (2002). Individualism, collectivism, and opportunism: a cultural perspective on transaction cost economics. Journal of Management, $28,567$. http://dx/doi.org/10.1177/014920630202800405

Chen, M., Lapaugh, A. S., \& Singh, J. P. (2002). Predicting category accesses for a user in a structured information space. Proceedings of the 25th Annual International ACM SIGIR Conference on Research and development in information retrieval (SIGIR'02), 65-72. http://dx.doi.org/10.1145/564376.564390

Cleveland, M., \& Laroche, M. (2007). Acculturation to the global consumer culture: scale development and research paradigm. Journal of Business Research, 60(3), 249-260. http://dx.doi.org/10.1016/j.jbusres.2006.11.006

Coase, R. H. (1937). The nature of the firm. Economica, 16(4), 386-405. http://dx.doi.org/10.1111/j.1468-0335.1937.tb00002.x

Coase, R. H. (1960). The problem of social cost. Journal of Law and Economics, 3, 1-44. http://dx.doi.org/10.1086/466560

Commons, J. R. (1990). Institutional Economics. Its Place in Political Economy. The Mac Millan Company: Transaction Publishers.

Conner, K. R., \& Prahalad, C. K. (1996). A resource-based theory of the firm: Knowledge versus opportunism. Organization Science, 7, 477-501. http://dx.doi.org/10.1287/orsc.7.5.477

Davidson, R., \& MacKinnon, J. G. (1989). Testing for consistency using artificial regressions. Econom Theory, 5, 363-384. http://dx.doi.org/10.1017/S0266466600012573

Davidson, R., \& MacKinnon, J. G. (1993). Estimation and Inference in Econometrics. New York: Oxford University Press.

De Jong, E. (2011). Culture, institutions and economic growth. Journal of Institutional Economics, 7(4). http://dx/doi.org /10.1017/S1744137411000117

De Mooij, M. (1998). Global Marketing and Advertising. Understanding Cultural Paradoxes. Thousand Oaks, CA: Sage Publications.

Dutt, A. K. (2011). Institutional change and economic development: concepts, theory and political economy. Journal of Institutional Economics, 7(4). http://dx/doi.org \10.1017/S1744137411000075

Easterly, W., Ritzen, J., \& Woolcock, M. (2006). Social cohesion, institutions and growth. Economics and 
Politics, 18(2), 103-120. http://dx.doi.org/10.1111/j.1468-0343.2006.00165.x

Economides, M. J., \& Ehlig-Economides, C. A. (2009). Sequestering carbon dioxide in a closed underground volume. SPE 124430, University of Houston.

Freytag, A., \& Thurik, R. (2007). Entrepreneurship and its determinants in a cross-country setting. Journal of Evolutionary Economics, 17(2), 117-131. http://dx.doi.org/10.1007/s00191-006-0044-2

Freytag, A., \& Thurik, R. (2010). Entrepreneurship and Culture. Heidelberg: Springer. http://dx.doi.org/10.1007/978-3-540-87910-7

Gazendam, L., \& Jorna, R. J. (2005). Transaction cost economics and plausible actors: a cognitive reappraisal. Position paper of Risk, Trust and Civility: A Pluridisciplinary Symposium. Victoria College, May 6-8.

Ghoshal, S., \& Moran, P. (1996). Bad for practice: A critique of the transaction cost theory. Academy of Management Review, 21, 13-47.

Greif, A. (1994). Cultural beliefs and the organization of society: A historical and theoretical reflection on collectivist and individualist societies. Journal of Political Economy, 102(5), 912-50. http://dx.doi.org/10.1086/261959

Grilo, I., \& Thurik, A. R. (2005). Entrepreneurial Engagement Levels in the European Union. Int. J. of Entrep. Educ., 3(2), 143-168.

Hausman, J. A. (1978). Specification tests in Econometrics. Econometrica, 46, 1251-1271. http://dx.doi.org/10.2307/1913827

Hédoin, C. (2012). Linking institutions to economic performance: the role of macro-structures in micro-explanations. Journal of Institutional Economics. http://dx/doi.org /10.1017/S1744137412000045

Hellman, J. S., Jones, G., Kaufmann, D., \& Schankerman, M. (2000). Measuring Governance, Corruption and State Capture: How Firms and Bureaucrats Shape the Business Environment in Transition Economies'. WB Policy Research, Working Paper, 2444. Washington, DC: World Bank.

Hoffmann, A. N. (2007). A Rough Guide to Entrepreneurship Policy. In D. Audretsch, I. Grilo, \& R. Thurik (Eds.), The Handbook of Entrepreneurship Policy (pp. 94-129). Cheltenham: Edward Elgar.

Hofstede et al. (2008a). Announcing a new version of the Values Survey Module: the VSM 08. Retrieved from http://stuwww.uvt.nl/ csmeets/VSM08.html

Hofstede et al. (2008b). Values Survey Module 2008 Manual. Retrieved from http://www.geerthofstede.nl/media/229/manualvsm08.doc

Hofstede, G. (1980). Culture's Consequences: International differences in Work-related Values. Beverly Hills CA: Sage Publ.

Hofstede, G. (1991). Cultures and Organizations: Software of the Mind. London: McGraw-Hill.

Hofstede, G. (1994). Cultures and Organizations. London: Harper Collins Publishers.

Hofstede, G. (2001). Culture’s Consequences. Beverly Hills: Sage.

House, R. J., Hanges, P. J., Javidan, M., Dorfman, P. W., \& Gupta, V. (2004). Culture, Leadership and Organisations - The GLOBE study of 62 societies. Thousand Oaks, CA: Sage Publ.

Hwang, H., \& Powell, W. W. (2005). Institutions and Entrepreneurship. In S. Alvarez, R. Argarwal, \& O. Sorenson (Eds.), Handbook of Entrepreneurship Research. Disciplinary Perspectives (pp. 201-232). New York: Springer. http://dx.doi.org/10.1007/0-387-23622-8_10

Kaufmann, D., Kraay, A., \& Mastruzzi, M. (2008). Governance Matters VII: Aggregate and Individual Governance Indicators, 1996-2007. WB Policy Research, Working Paper, 4654. Washington, DC: World Bank.

Kaufmann, D., Kraay, A., \& Zoido-Lobatón, P. (1999). Governance Matters. WB Policy Research, Working Paper, 2196. Washington, DC: World Bank.

Kluckhohn, C. (1954). Culture and Behavior. New York: Free Press.

Kluckhohn, C., \& Kroeber, A. L. (1952). Culture: A Critical Review of Concepts and Definitions. Cambridge, Mass: The Museum.

Kluckhohn, C., \& Strodtbeck, F. (1961). Variations in Value Orientations. Evanston, Illinois: Row, Peterson. 
Knight, F. H. (1971). Risk, uncertainly, and profit. Chicago, IL: The University of Chicago Press.

McClelland, D. C. (1961). The Achieving Society. Princeton: D. Van Nostrand Company.

Minkov, M., \& Blagoev, V. (2009). Cultural values predict subsequent economic growth. International Journal of Cross-Cultural Management, 9(1), 5-24. http://dx.doi.org/10.1177/1470595808101153

North, D. C. (1981). Structure and Change in Economic History. New York: WW Norton \& Company.

North, D. C. (1990). Institutions, Institutional Change and Economic Performance. Cambridge: Cambridge University Press. http://dx.doi.org/10.1017/CBO9780511808678

Oyserman, D., \& Sorensen, N. (2009). Understanding cultural syndrome effects on what and how we think: A situated cognition model. In C. Chiu, R. Wyer Jr, \& Y. Hong (Eds.), Understanding culture: Theory, research and application (pp. 25-52). New York: Psychology Press.

Parker, S. (2007). Policy-makers Beware! In D. Audretsch, I. Grilo, \& R. Thurik (Eds.), The Handbook of Entrepreneurship Policy (pp. 54-63). Cheltenham: Edward Elgar.

Rapp, J., Bernardi, R., \& Bosco, S. (2011). Examining The Use of Hofstede's Uncertainty Avoidance Construct in International Research: A 25-Year Review. International Business Research, 4(1), 3-15.

Schumpeter, J. (1934). The Theory of Economic Development. Massachusetts: Harvard University Press.

Schumpeter, J. (1950). Capitalism, Socialism and Democracy. New York: Harper and Row.

Schwarz, S. H. (2009). Culture Matters: National value cultures, Sources, and Consequences. In R. S. Wyer et al. (Eds.), Understanding Culture. New York: Psychology Press.

Shane, S. A. (1992). The effect of cultural differences in perceptions of transaction costs on national differences in the preference for licensing. Management International Review, 32(5), 295-311.

Shane, S. A. (1993). Cultural influences on national rates on innovation. Journal of Business Venturing, 8, 59-73. http://dx.doi.org/10.1016/0883-9026(93)90011-S

Smith, L. (2002). Tutorial on Principal Components Analysis. Retrieved from http://www.cs.otago.ac.nz/cosc453/student_tutorials/principal_components.pdf

Spithoven, A. (2012). Public governance of healthcare in the United States: a transaction cost economics (TCE) analysis of the 2010 reform. Journal of Institutional Economics. http://dx/doi.org/10.1017/S1744137412000082

Spranz, R., Lenger, A., \& Goldscmidt, N. (2012). The relation between institutional and cultural factors in economic development: the case of Indonesia. Journal of Institutional Economics. http://dx/doi.org/10.1017/S1744137412000124

Spulber, D. F. (2003). The Intermediation Theory of the Firm: Integrating Economic and Management Approaches to Strategy. Manag and Decis Econ, 24, 253-266. http://dx.doi.org/10.1002/mde.1120

Spulber, D. F. (2008). The Economic Role of the Entrepreneur. Retrieved from http://lawlab.org/EconomicRoleoftheEntrepreneur.pdf

Stevenson, L., \& Lundström, A. (2005). Entrepreneurship Policy for the Future: Best Practice Components. In R. van der Horst, S. King-Kauanui, \& S. Duffy (Eds.), Keystones of Entrepreneurship Knowledge (pp. 177-194). Oxford: Blackwell Publishing.

Stevenson, L., \& Lundström, A. (2007). Dressing the Emperor: The Fabric of Entrepreneurship Policy. In D. Audretsch, I. Grilo, \& R. Thurik, (Eds.), The Handbook of Entrepreneurship Policy (pp. 94-129). Cheltenham: Edward Elgar.

Triandis, H. C. (1994). Culture and Social Behavior. New York: McGraw-Hill.

Triandis, H. C. (1996). The psychological measurement of cultural syndromes. American Psychologist, 51(4), 407-415. http://dx.doi.org/10.1037/0003-066X.51.4.407

van Stel, A., Carree, M., \& Thurik, A. R. (2005). The Effect of Entrepreneurial Activity on National Economic Growth. Small Bus Econ, 24(3), 311-321. http://dx.doi.org/10.1007/s11187-005-1996-6

van Stel, A., Storey, D. J., \& Thurik, R. (2007). The effect of business regulations on nascent and young business entrepreneurship. Small Bus Econ, 28, 171-186. http://dx.doi.org/10.1007/s11187-006-9014-1

Verheul, I., Wennekers, A. R. M., Audretsch, D., \& Thurik, A. R. (2002). An eclectic theory of entrepreneurship. 
In D. Audretsch, A. R. Thurik, I. Verheul, \& A. R. M. Wennekers (Eds.), Entrepreneurship: determinants and policy in a European-US comparison (pp. 11-81). Boston, MA: Kluwer. http://dx.doi.org/10.1007/0-306-47556-1_2

Volkema, R. J. (1999). The Negotiation Toolkit: How to get exactly what you want in any Business or Personal Situation. New York: AMACOM.

Wang, R. (2012). Chinese Culture and its Potential Influence on Entrepreneurship. International Business Research, 5(10), 76-90. http://dx.doi.org/10.5539/ibr.v5n10p76

Weber, M. (1996). The Protestant Ethic and the Spirit of Capitalism. (T Parsons Trans.). Los Angeles: Roxbury.

Wennekers, A. R. M., Thurik, A. R., van Stel, A. J., \& Noorderhaven, N. (2008). Uncertainty avoidance and the rate of business ownership across 21 OECD countries, 1976-2004. J. of Evol. Econ., 17(2), 133-160. http://dx.doi.org/10.1007/s00191-006-0045-1

Wennekers, A. R. M., Uhlaner, L., \& Thurik, A. R. (2002). Entrepreneurship and its conditions: a macro perspective. Int. J. of Entrep. Educ., I(1), 25-64.

Williamson, O. (1975). Markets and Hierarchies: Analysis and Antitrust Implications. New York: Free Press.

Williamson, O. (1981). The economics of organization: The transaction cost approach. The Am. J. of Sociol., 87, 548-577. http://dx.doi.org/10.1086/227496

Williamson, O. (1985). The Economic Institutions of Capitalism: Firms, markets, relational contracting. New York: Free Press.

Williamson, O., Hodgson, G. M., \& Gindis, D. (2007). An Interview with Oliver Williamson. Journal of Institutional Economics, 3, 373-386.

\section{Note}

Note 1. Hofstede specifies five cultural dimensions: the power distance (indicating the extent to which a society accepts the unequal distribution of power amongst its members), individualism/collectivism (the degree to which people in a country learn to act more as individuals than as members of a group), masculinity/femininity (the extent to which "masculine" values such as good performance, success and competition prevail over "feminine" values, such as quality of life, maintaining warm personal relationships, service, caring for the weak and solidarity), uncertainty avoidance (referring to the lack of tolerance a society shows towards uncertainty and doubt) and short-term/long term orientation (formerly called Confucian dynamism, it separates short-term oriented cultures from long-term-oriented cultures, based on the dimensions of orientation towards the past, present and future suggested by Kluckhohn and Strodtbeck (1961). 